\title{
Hydrocortisone reduces postoperative shivering following day care knee arthroscopy
}

\section{L'hydrocortisone réduit le frisson postopératoire après une arthroscopie du genou en ambulatoire}

\author{
Manjeet Singh Pawar, MD • Neelam Suri, MD • \\ Naresh Kaul, MD · Shobha Lad, MD • \\ Rashid Manzoor Khan, MD
}

Received: 17 November 2010/Accepted: 14 July 2011/Published online: 25 August 2011

(c) Canadian Anesthesiologists' Society 2011

\begin{abstract}
Purpose Postoperative shivering is commonly observed in patients after general anesthesia. A double-blind randomized controlled trial was conducted in patients undergoing day care knee arthroscopy to test the hypothesis that a single intraoperative dose of hydrocortisone would prevent or attenuate postoperative shivering.

Methods One hundred and twenty patients were given a nitrous oxide-isoflurane-remifentanil anesthetic. Approximately ten minutes before the end of anesthesia, they were randomized to receive normal saline (Control group; $n=40$ ); hydrocortisone $1 \mathrm{mg} \cdot \mathrm{kg}^{-1}$ iv (Hydrocortisone-1 group; $\mathrm{n=} 40$ ), or hydrocortisone $2 \mathrm{mg} \cdot \mathrm{kg}^{-1}$ iv (Hydrocortisone-2 group; $n=40$ ). Postoperative shivering was graded by a blinded observer using a five-point scale: Grade 0: none; Grade 1: one or more areas of piloerection but without visible muscular activity; Grade 2: visible muscular activity confined to one muscle group; Grade 3: same as Grade 2 but in more than one muscle group; and Grade 4: gross muscular activity involving the entire body. Results Shivering (Grades 1-4) was observed in 33 patients (82\%) in the Control group, 13 patients (32\%) in the Hydrocortisone-1 group $(P<0.001$ compared with the Control group), and eight patients (20\%) in the Hydrocortisone-2 group $(P<0.001$ compared with the Control
\end{abstract}

M. S. Pawar, MD · N. Suri, MD - N. Kaul, MD · S. Lad, MD ·

R. M. Khan, MD

Department of Anaesthesia and ICU, National Trauma Center, Khoula Hospital, Muscat, Sultanate of Oman

M. S. Pawar, MD ( $\square)$

KIMS Oman Hospital, P.O. Box 1522, Jibroo, Muscat 114, Sultanate of Oman

e-mail: manjitshimla@hotmail.com group). The overall incidence of shivering was similar in the Hydrocortisone-1 and Hydrocortisone-2 groups.

Conclusions This study shows that hydrocortisone $\left(1-2 \mathrm{mg} \cdot \mathrm{kg}^{-1}\right.$ iv) provides effective prophylaxis against postoperative shivering in patients undergoing day care knee arthroscopy under general anesthesia.

\section{Résumé}

Objectif Le frisson postopératoire est fréquemment observé chez les patients après une anesthésie générale. Une étude randomisée contrôlée à double insu a été réalisée chez des patients subissant une arthroscopie du genou en ambulatoire pour tester l'hypothèse qu'une dose peropératoire unique d'hydrocortisone préviendrait ou atténuerait le frisson postopératoire.

Méthode Cent vingt patients ont reçu un anesthésique à base de protoxyde d'azote, d'isoflurane et de rémifentanil. Environ dix minutes avant la fin de l'anesthésie, les patients ont été randomisés à recevoir soit un normal salin (groupe témoin; $n=40$ ), $1 \mathrm{mg} \cdot \mathrm{kg}^{-1}$ d'hydrocortisone iv (groupe hydrocortisone-1; $n=40$ ) ou $2 \mathrm{mg} \cdot \mathrm{kg}^{-1}$ d'hydrocortisone iv (groupe hydrocortisone-2; $n=40$ ). Le frisson postopératoire a été évalué par un observateur en aveugle à l'aide d'une échelle à cinq points: 0: aucun; 1: une ou plusieurs zones d'horripilation mais sans activité musculaire visible; 2: activité musculaire visible confinée à un groupe de muscles; 3: idem que 2 mais dans plus d'un groupe de muscles; et 4: activité musculaire non spécifique au niveau du corps entier.

Résultats Des frissons (notes 1-4) ont été observés chez 33 patients $(82 \%)$ dans le groupe témoin, 13 patients (32\%) dans le groupe hydrocortisone-1 $(P<0,001$ par rapport au groupe témoin) et huit patients (20\%) dans le groupe hydrocortisone-2 $(P<0,001$ par rapport au groupe témoin). La fréquence globale de frissons 
était semblable dans les groupes hydrocortisone-1 et hydrocortisone- 2 .

Conclusion Cette étude démontre que l'hydrocortisone (1-2 $\left.\mathrm{mg} \cdot \mathrm{kg}^{-1} \mathrm{iv}\right)$ procure une prophylaxie efficace contre le frisson postopératoire chez les patients subissant une arthroscopie du genou en ambulatoire sous anesthésie générale.

Postoperative shivering is commonly observed in patients recovering from general anesthesia, ${ }^{1}$ and an incidence of $57 \%$ has been reported in patients undergoing arthroscopy. ${ }^{2}$ Perioperative hypothermia occurs by dysfunction of the thermoregulatory system because of anesthetic drugs and the patient's contact with the cold environment of an operating room. However, it has been reported that postoperative shivering is not prevented by either intraoperative or combined intraoperative and postoperative warming. ${ }^{3}$ A number of other factors, such as uninhibited spinal reflexes, pain, decreased sympathetic activity, adrenal suppression, release of pyrogenic mediators during surgery, administration of volatile anesthetics, opiate withdrawal, blood loss, and duration of surgery may also contribute to thermoregulatory shivering in response to hypothermia., ${ }^{1,4}$ Postanesthesia shivering can produce cardiovascular, hemorrhagic, and infectious complications which can lead to prolonged hospital admission. It also increases the oxygen requirements of the body. ${ }^{4}$

Various drugs, such as meperidine, clonidine, or ketamine, have been used to control postoperative shivering. ${ }^{4-7}$ However, the use of these drugs is associated with various side effects, such as sedation, hallucination, or delayed recovery from anesthesia. ${ }^{5,6}$ Hydrocortisone has been used as an anti-inflammatory agent for a long time. ${ }^{8}$ It also influences protein, fat, carbohydrate, and purine metabolism; it affects water and electrolyte balance and exerts a direct calorigenic effect ${ }^{9}$ which might be useful in attenuating or preventing postoperative shivering.

General anesthesia is routinely administered for elective knee arthroscopy at our tertiary care hospital. It is common to note shivering in our patients in the recovery room. We hypothesized that a single dose of hydrocortisone administered approximately ten minutes before the conclusion of surgery would be effective in preventing or attenuating postoperative shivering following general anesthesia.

\section{Methods}

After approval by the Hospital Ethical Committee of Khoula Hospital, Muscat, Oman, we enrolled 120 adult patients of either sex (American Society of Anesthesiologists [ASA] physical status I-II) in this prospective randomized double-blind study. All patients were undergoing general anesthesia for elective knee arthroscopy in our National Trauma Centre. Patients with diabetes, hypertension, peptic ulcer, or those on prolonged steroid therapy were excluded from the study. Patients were randomly allocated to one of three groups on the basis of a manual envelope randomization technique. Forty envelopes for each of the three groups were kept mixed in a box. After screening the patient and noting his/her appropriateness for the study, an envelope was withdrawn from the box and opened by a designated researcher just prior to taking the patient to the operating room. This researcher prepared the saline or hydrocortisone solution as per the envelope. The person injecting the drug was unaware of the group allocation. Approximately ten minutes before completion of surgery, patients in the Control group $(n=40)$ received normal saline $5 \mathrm{~mL}$; patients in the Hydrocortisone- 1 group $(n=40)$ received hydrocortisone $1 \mathrm{mg} \cdot \mathrm{kg}^{-1} \mathrm{iv}$; and patients in the Hydrocortisone- 2 group $(n=40)$ received hydrocortisone $2 \mathrm{mg} \cdot \mathrm{kg}^{-1} i v$ in $5 \mathrm{~mL}$ of normal saline.

All patients were premedicated with midazolam $7.5 \mathrm{mg}$ orally approximately one hour prior to surgery. General anesthesia was induced with propofol $2 \mathrm{mg} \mathrm{kg}^{-1}$, remifentanil $1 \mu \mathrm{g} \cdot \mathrm{kg}^{-1}$, and atracurium $0.6 \mathrm{mg} \cdot \mathrm{kg}^{-1}$. Following adequate paralysis, the patient's trachea was intubated. Anesthesia was maintained with $60 \% \mathrm{~N}_{2} \mathrm{O}$ in $\mathrm{O}_{2}, 0.5-2 \%$ isoflurane, and an infusion of remifentanil 5-8 $\mu \mathrm{g} \cdot \mathrm{kg}^{-1} \cdot \mathrm{hr}^{-1}$ to keep changes in blood pressure within $20 \%$ of the preinduction values. Nasopharyngeal temperature was recorded using a S/5 Aespire probe (Datex Ohmeda 7100 GE Health Care, Helsinki, Finland) inserted nasally after induction of anesthesia and left in place until tracheal extubation. The operating room temperature was kept constant at $23(1)^{\circ} \mathrm{C}$. Other than surgical drapes, no other warming device was used intraoperatively. Intravenous fluids (Lactated Ringer's solution) were administered at room temperature. Approximately ten minutes before the end of surgery, the study drug was administered intravenously along with fentanyl $0.5 \mu \mathrm{g} \cdot \mathrm{kg}^{-1}$. At the conclusion of surgery, residual neuromuscular blockade was reversed using a mixture of neostigmine $2.5 \mathrm{mg}$ and glycopyrrolate $0.4 \mathrm{mg} i v$. Tracheal extubation was performed after the patient started to obey verbal commands. Patients were then transferred to the recovery room for further observation for approximately one hour. A recovery staff nurse, who was responsible for the care of two patients at any given time and blinded to the treatment group, graded postoperative shivering using a five-point scale as follows:

Grade 0: None;

Grade 1: One or more areas of piloerection but without visible muscular activity; 
Grade 2: Visible muscular activity confined to one muscle group;

Grade 3: Same as Grade 2 but in more than one muscle group; and

Grade 4: Gross muscular activity involving the entire body.

Patients showing any grade of breakthrough shivering were provided with a warming blanket (Bair Hugger ${ }^{\circledR}$ warming unit, Arizant Healthcare Inc., Eden Prairie MN, USA). Persistent shivering was treated with meperidine $20 \mathrm{mg} i v$ if the shivering grade was $\geq 2$. $^{7}$ If shivering still persisted, hydrocortisone $100 \mathrm{mg}$ was administered.

The primary outcome measurement was absence of postoperative shivering. Sample size was calculated using the sample size calculator at www.epibiostat.ucsf.edu/ biostat. We expected the incidence of shivering to decrease from $57 \%$ in the control population to $24 \%$ with hydrocortisone treatment. ${ }^{2}$ Calculations based on the significance level (alpha) of 0.05 and power (beta) of 80 gives 34 as the minimum number of patients per group, and we selected a sample size of 40 patients in each group.

All data are presented as mean (standard deviation) unless otherwise indicated. Data were analyzed using unpaired Student's $t$ test; Chi square test was used to analyze the incidence of shivering in the different groups. Patients in different groups showing shivering of any grade were pooled for the analysis. Hydrocortisone-1 and Hydrocortisone-2 groups were compared with the Control group as well as with each other. A $P$ value $<0.05$ was considered as significant. SPSS 14 program (SPSS Inc., Chicago, IL, USA) was used for statistical analysis.

\section{Results}

One hundred and thirty one patients were screened and 120 patients met eligibility criteria and were enrolled, consented and randomized. All of the 120 enrolled patients completed the trial. The study was conducted during 2009-2010 and was completed upon acquiring the required sample size in each group.

Age, sex, and ASA physical status were similar in all groups (Table 1). Duration of surgery, amount of irrigation fluid used, and change in nasopharyngeal temperature were also similar in all three groups (Table 2). Cumulative doses of remifentanil (298-324 $\mu \mathrm{g}$ ) and fentanyl (32.4-33.0 $\mu \mathrm{g}$ ) were also similar in all three groups. All of our patients showed awakening within three to five minutes after reversal of residual neuromuscular blockade, and tracheal extubation could be performed immediately thereafter.

The incidence of shivering was significantly $(P<0.001)$ lower in the hydrocortisone groups, i.e., $32 \%$ and $20 \%$ in
Table 1 Demographic data

\begin{tabular}{llll}
\hline & $\begin{array}{l}\text { Control } \\
n=40\end{array}$ & $\begin{array}{l}\text { Hydrocortisone-1 } \\
n=40\end{array}$ & $\begin{array}{l}\text { Hydrocortisone-2 } \\
n=40\end{array}$ \\
\hline Age (yr) & $25.7(3.9)$ & $26.5(5.4)$ & $26.4(5.2)$ \\
Sex (M/F) & $39 / 1$ & $37 / 3$ & $35 / 5$ \\
ASA I/II & $20 / 20$ & $28 / 12$ & $22 / 18$
\end{tabular}

Control group received saline. Hydrocortisone-1 group received hydrocortisone $1 \mathrm{mg} \cdot \mathrm{kg}^{-1} i v$; Hydrocortisone-2 group received hydrocortisone $2 \mathrm{mg} \cdot \mathrm{kg}^{-1}$ iv. $n=$ number of patients; ASA $\mathrm{I} / \mathrm{II}=$ American Society of Anesthesiologists' grading I or II.

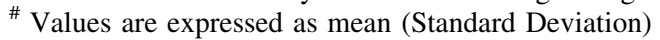

the Hydrocortisone- 1 and Hydrocortisone- 2 groups, respectively, compared with $82 \%$ in the Control group (Table 3). There was no difference in the overall incidence of shivering when comparing the Hydrocortisone-1 and Hydrocortisone-2 groups $(P=0.204)$.

Of the 21 patients receiving hydrocortisone (13 in Hydrocortisone-1 and eight in Hydrocortisone-2) who shivered, all except one responded to a warm blanket within ten minutes. However, only six of the 33 patients in the Control group who developed postoperative shivering responded to a warm blanket. The remaining 27 patients required meperidine; 18 of these patients responded within ten minutes, and the remaining nine patients were given hydrocortisone as well. One patient in the Hydrocortisone-2 group and one in the Control group did not respond to any treatment, and they continued to have Grade 2 shivering for $30 \mathrm{~min}$.

\section{Discussion}

The results of this study show the prophylactic effect of hydrocortisone on postoperative shivering following knee arthroscopy. There was a significant reduction in the incidence of post arthroscopy shivering from $82 \%$ in the Control group compared to $32 \%$ in the Hydrocortisone-1 group and $20 \%$ in the Hydrocortisone- 2 group. In addition, intensity of shivering was much milder in patients receiving hydrocortisone before conclusion of arthroscopy. The Hydrocortisone-1 and Hydrocortisone-2 groups were not significantly different from each other with respect to the incidence of shivering. The maximum dose of hydrocortisone was selected as $2 \mathrm{mg} \cdot \mathrm{kg}^{-1}$ because this dose has been shown to be effective in treating transfusion and drugrelated reactions in the postoperative period. ${ }^{10}$

We observed a higher incidence of shivering in the Control group patients $(82 \%)$ than in earlier studies, ${ }^{1,2}$ which may be attributed to two reasons. First, our patients were young and healthy with good muscle mass. Second, 
Table 2 Intraoperative data

\begin{tabular}{llllll}
\hline Groups & $\begin{array}{l}\text { Duration } \\
\text { of surgery } \\
(\mathrm{min})\end{array}$ & $\begin{array}{l}\text { Volume } \\
\text { of irrigation } \\
\text { fluid }(\mathrm{mL})\end{array}$ & $\begin{array}{l}\text { Nasopharyngeal } \\
\text { temperature before } \\
\text { surgery }\left({ }^{\circ} \mathrm{C}\right)\end{array}$ & $\begin{array}{l}\text { Nasopharyngeal } \\
\text { temperature after } \\
\text { surgery }\left({ }^{\circ} \mathrm{C}\right)\end{array}$ & $\begin{array}{l}\text { Change in } \\
\text { nasopharyngeal } \\
\text { temperature }\left({ }^{\circ} \mathrm{C}\right)\end{array}$ \\
\hline Control & $42.8(12.6)$ & $2,675(660)$ & $35.7(0.1)$ & $34.7(0.1)$ & $-1.0(0.1)$ \\
Hydrocortisone-1 group & $42.2(12.1)$ & $2,585(672)$ & $35.7(0.1)$ & $34.6(0.1)$ & $-1.1(0.2)$ \\
Hydrocortisone-2 group & $38.6(8.6)$ & $2,707(726)$ & $35.7(0.1)$ & $34.6(0.1)$ & $-1.1(0.2)$ \\
\hline
\end{tabular}

Values are expressed as mean (Standard Deviation). Control group received saline

Hydrocortisone-1 group received hydrocortisone $1 \mathrm{mg} \cdot \mathrm{kg}^{-1} i v$; Hydrocortisone-2 group received hydrocortisone $2 \mathrm{mg} \cdot \mathrm{kg}^{-1} i v$

Table 3 Incidence and severity of shivering

\begin{tabular}{|c|c|c|c|c|c|c|}
\hline \multirow[t]{2}{*}{ Groups } & \multicolumn{5}{|c|}{ Grades of shivering } & \multirow{2}{*}{$\begin{array}{l}\text { Number of } \\
\text { patients } \\
\text { shivering } \\
n(\%)\end{array}$} \\
\hline & $\begin{array}{l}\text { Grade } 0 \\
n(\%)\end{array}$ & $\begin{array}{l}\text { Grade } 1 \\
n(\%)\end{array}$ & $\begin{array}{l}\text { Grade } 2 \\
n(\%)\end{array}$ & $\begin{array}{l}\text { Grade } 3 \\
n(\%)\end{array}$ & $\begin{array}{l}\text { Grade } 4 \\
n(\%)\end{array}$ & \\
\hline Control & 7 (17) & $2(5)$ & $15(37)$ & $12(30)$ & $4(10)$ & $33(82)$ \\
\hline Hydrocortisone-1 & $27(67)$ & $4(10)$ & $5(12)$ & $2(5)$ & $2(5)$ & $13(32)^{*}$ \\
\hline Hydrocortisone-2 & $32(80)$ & $2(5)$ & $2(5)$ & $2(5)$ & $2(5)$ & $8(20)^{*}$ \\
\hline
\end{tabular}

Control group received saline. Hydrocortisone-1 group received hydrocortisone $1 \mathrm{mg} \cdot \mathrm{kg}^{-1} \mathrm{iv}$; Hydrocortisone-2 group received hydrocortisone $2 \mathrm{mg} \cdot \mathrm{kg}^{-1} i v . n=$ number of patients; $\%=$ percentage of patients. *Significantly $(P<0.001)$ different compared with the Control group. ${ }^{\top} P=0.204$ compared with the Hydrocortisone-1 group

our patients received irrigation fluid at room temperature as part of the surgical procedure.

In this study, age, sex, and ASA grade distribution of patients were nearly identical in the three groups. Furthermore, the duration of surgery and amount of irrigation fluid used in the three different groups were also similar. We did not observe a change in temperature gradient between the three groups since only ten minutes elapsed from administration of hydrocortisone to the recording of the final temperature reading. A study with a more prolonged duration of postoperative temperature monitoring is needed to note if core-periphery temperature changes occur with passage of time.

The exact mechanism by which hydrocortisone prevents shivering is not known. A few animal studies ${ }^{11-14}$ suggest that glucocorticoids have an anabolic effect with an increase in hepatic ATP levels. Exposure of cows to high temperature $\left(31^{\circ} \mathrm{C}\right)$ for a long period of time (eight weeks) caused a depression in the plasma hydrocortisone secretion rate, ${ }^{11,15}$ indicating a possible role of hydrocortisone in thermoregulatory mechanisms. In addition, glucocorticoids have been shown to exert a number of rapid actions which are independent of the regulations of gene transcription. ${ }^{16}$ The effect of hydrocortisone could also be mediated through alterations in thyroid hormone metabolism ${ }^{17}$ or nitric oxide synthase activity. ${ }^{18}$

An important limitation of this study was that the sample population consisted mostly of young adult male patients who were relatively healthy. It needs to be determined whether the present findings can be generalized to other age groups and the female sex. In addition, this study made no attempt to assess whether these young patients could benefit from other simple measures, such as peroperative warming, more opioid analgesics, or intravenous anesthetics. We did not look specifically for non-hemodynamic side effects. However, a single low dose (100-200 mg) of hydrocortisone ${ }^{8,19}$ is not known to have adverse immunologic or hemodynamic effects. ${ }^{10,20}$ Absence of infection and normal wound healing has also been noted in all of the patients given hydrocortisone to reduce inflammation during bilateral total knee replacement. ${ }^{19}$

In conclusion, this study demonstrates that hydrocortisone $\left(1-2 \mathrm{mg} \cdot \mathrm{kg}^{-1} \mathrm{iv}\right)$ provides effective prophylaxis against postoperative shivering in patients undergoing day care knee arthroscopy under general anesthesia.

Funding sources None.

Any other association, such as consultancies None.

Conflict of interest None declared.

\section{References}

1. Leslie K, Sessler DI. Perioperative hypothermia in the high-risk surgical patient. Best Pract Res Clin Anaesthesiol 2003; 17: 485-98. 
2. Powell RM, Buggy DJ. Ondansetron given before induction of anesthesia reduces shivering after general anesthesia. Anesth Analg 2000; 90: 1423-7.

3. Smith I, Newson CD, White PF. Use of forced-air warming during and after outpatient arthroscopic surgery. Anesth Analg 1994; 78: 836-41.

4. Putzu M, Casati A, Berti M, Pagliarini G, Fanelli G. Clinical complications, monitoring and management of perioperative mild hypothermia: anaesthesiological features. Acta Biomed 2007; 78: 163-9.

5. Kim MS, Kim DW, Woo S-H, Yon JH, Lee S. Effect of ramosetron on shivering during spinal anesthesia. Korean J Anesthesiol 2010; 58: 256-9.

6. Wrench IJ, Cavill G, Ward JEH, Crossley AWA. Comparison between alfentanil, pethidine and placebo in the treatment of post-anaesthetic shivering. Br J Anaesth 1997; 79: 541-2.

7. Sagir O, Gulhas N, Toprak H, Yucel A, Begec Z, Ersoy O. Control of shivering during regional anaesthesia: prophylactic ketamine and granisetron. Acta Anaesthesiol Scand 2007; 51: 44-9.

8. Keh D, Boehnke T, Weber-Cartens $S$, et al. Immunologic and hemodynamic effects of "low-dose" hydrocortisone in septic shock: a double-blind, randomized, placebo-controlled, crossover study. Am J Respir Crit Care Med 2003; 167: 512-20.

9. Evans ES, Contopoulos AN, Simpson ME. Hormonal factors influencing calorigenesis. Endocrinology 1957; 60: 403-19.

10. Kaufmann I, Briegel J, Schliephake F, et al. Stress doses of hydrocortisone in septic shock: beneficial effects on opsonization-dependent neutrophil functions. Intensive Care Med 2008; 34: $344-9$
11. Yousef MK, Johnson HD. Calorigenesis of cattle as influenced by hydrocortisone and environmental temperature. J Anim Sci 1967; 26: 1087-93.

12. O'Neill IE, Langslow DR. The action of hydrocortisone, insulin, and glucagon on chicken liver hexokinase and glucose-6-phosphatase and on the plasma glucose and free fatty acid concentrations. Gen Comp Endocrinol 1978; 34: 428-37.

13. Feigelson P, Feigelson M. Studies on the mechanism of regulation by cortisone of the metabolism of liver purine and ribonucleic acid. J Biol Chem 1963; 238: 1073-7.

14. Feigelson M, Gross P, Feigelson P. Early effect of cortisone on nucleic acid and protein metabolism of rat liver. Biochim Biophys Acta 1962; 55: 495-504.

15. Christison GI, Johnson HD. Cortisol turnover in heat-stressed cows. J Anim Sci 1972; 35: 1005-10.

16. Alangari $A A$. Genomic and non-genomic actions of glucocorticoids in asthma. Ann Thorac Med 2010; 5: 133-9.

17. Samuels MH, Luther $M$, Henry P, Ridgway EC. Effects of hydrocortisone on pulsatile pituitary glycoprotein secretion. J Clin Endocrinol Metab 1994; 78: 211-5.

18. Hafezi-Moghadam A, Simoncini T, Yang Z, et al. Acute cardiovascular protective effects of corticosteroids are mediated by non-transcriptional activation of endothelial nitric oxide synthase. Nat Med 2002; 8: 473-9.

19. Jules-Elysee KM, Lipnitsky JY, Patel N, et al. Use of low-dose steroids in decreasing cytokine release during bilateral total knee replacement. Reg Anesth Pain Med 2011; 36: 36-40.

20. MacLaren R, Jung R. Stress-dose corticosteroid therapy for sepsis and acute lung injury or acute respiratory distress syndrome in critically ill adults. Pharmacotherapy 2002; 22: 1140-56. 